\title{
Dossiê "Recepção: Nietzsche no Brasil: núcleo histórico", parte III
}

Ensaios e comentários controversos sobre o "super-homem" nietzschiano publicados na no início do século XX.

\section{Nota preliminar}

A dimensão histórica de recepção da filosofia de Nietzsche no Brasil possui uma formidável pluralidade de abordagens das obras do filósofo. Dentre elas, Assim falava Zaratustra tem uma presença destacada, e, nela, deu-se particular atenção para a ideia do "super-homem": Übermensch. Nessa direção, alertamos para o fato de que todos os textos publicados neste dossiê foram atualizados segundo o acordo ortográfico vigente. Não obstante, no caso de alguns vocábulos estrangeiros e outros próprios da filosofia nietzschiana, optamos por não atualizar pela tradução corrente, a fim de conservar a identidade e o contexto histórico de cada escrito. Para os nomes próprios, adotamos a seguinte orientação: no caso do nome do filósofo, conservamos a maneira como cada texto o reproduz, uma vez que assim indicam as fontes estrangeiras pelas quais os autores tomaram contato com ele. Pela mesma razão, os nomes dos autores dos textos, bem como os nomes de autores e escritores que aparecem neles, os nomes de pessoas, de personagens, sejam da filosofia de Nietzsche ou de outros filósofos, de cidades e de expressões próprias da época foram conservados

Cad. Nietzsche, Guarulhos/Porto Seguro, v.36 n.2, p. 117-118, 2015. | 117 
Dias, G.

na grafia original de seus respectivos períodos, com rara exceção de alguns já fixados na ortografia atual. Por isso, utilizaremos do advérbio latino sic para evidenciar que o uso, às vezes incorreto e outras vezes incomum, seja de nomes de lugares, de pessoas ou de pontuação ortografia, seja de formatação presentes nos textos, provém de seu autor original. Contudo, quando verificarmos tratarse de óbvio erro de digitação, evitaremos o uso do sic e fazemos a correção.

Geraldo Dias (organizador do dossiê)

118 Cad. Nietzsche, Guarulhos/Porto Seguro, v.36 n.2, p. 117-118, 2015. 